\title{
RESEARCH ON THE INFLUENCE OF SPORT DANCE ON PHYSICAL HEALTH IN NATIONAL FITNESS EXERCISE
}

\author{
PESQUISA SOBRE A INFLUÊNCIA DA DANÇA ESPORTIVA NA SAÚDE FÍSICA NO EXERCÍCIO \\ DE CONDICIONAMENTO FÍSICONACIONAL \\ INVESTIGACIÓN SOBRE LA INFLUENCIA DE LA DANZA DEPORTIVA EN LA SALUD FÍSICA \\ ENEL EJERCICIO DEACONDICIONAMIENTO FISICO NACIONAL
}

\begin{abstract}
Caixia Wang 1 (ID
(Physical Education Professional) Lei $\mathrm{Li}^{2}$ (D)

(Physical Education Professional) Aibo Wang ${ }^{3}$ (D)

(Physical Education Professional)

1. Handan College, Handan, Hebei, China.

2. Hebei University of Science and Technology, Shijiazhuang, Hebei, China.

3. Hengshui College, Hengshui, Hebei, China.
\end{abstract}

\section{Correspondence:}

Aibo Wang

Hengshui College, Hengshui,

Hebei, China.

tiyuwudaojys@163.com

hssyhzp1974@126.com

\begin{abstract}
Introduction: Sports dance is widely known as a competitive game, but as a leisure activity, there is little research on the efficacy of human health and fitness. Sports dance, as a popular national fitness exercise, has sound health promotion effects. At present, domestic and foreign researches mostly focus on the impact of sports dance on young men and women. Objective: This study will explore the influence of regular physical dance exercises on the body shape, function, and quality of middle-aged and older adults, provide a scientific basis for the role of physical dance in national fitness. Methods: This study recruited 20 healthy middle-aged and elderly members of a leisure sports dance club without professional dance experience for three months of dance training. The first two weeks are pre-experiments five times a week. Each exercise time is 60 minutes. The last ten weeks are formal experiments, two times a week, 90 minutes each time, and no other physical exercises are involved in everyday life. By comparing part of the body shape, physical function, and physical fitness index before and after the experiment, the impact of sports dance on middle-aged and older adults' healthy physical fitness is evaluated. Results: After three months of physical dance exercise with different dance styles, in male, BMI index, body fat percentage, waist circumference, hip circumference, and thigh circumference indicators all decreased, but there was no significant difference. In women, BMl index, body fat percentage $(P<0.01)$, waist circumference $(P<0.05)$, diastolic blood pressure $(P<0.01)$, sitting body forward bending $(P<0.05)$, and standing with one foot and closed eyes all increased. In women, the indexes of grip strength $(P<0.01)$, forward bending in sitting position $(P<0.055)$, and standing with eyes closed on one foot all increased. Conclusions: It is suggested that long-term moderate-intensity aerobic sport dance exercise can improve the body shape of middle-aged and older adults and help increase physical fitness; meanwhile, sports dance can effectively improve the cardiovascular function of middle-aged and elderly subjects. Level of evidence Il; Therapeutic studies - investigation of treatment results.
\end{abstract}

Keywords: Dancing; Middle-aged and older adults; Activities; Exercise.

\section{RESUMO}

Introdução: A dança esportiva é amplamente conhecida como um jogo competitivo, mas como atividade de lazer, existem poucas pesquisas sobre sua eficácia na saúde e forma física humana. A dança esportiva, como exercício físico popular em âmbito nacional, tem importantes efeitos na promoção da saúde. Atualmente, a pesquisa nacional e estrangeira está focada principalmente no impacto da dança esportiva em jovens de ambos os sexos. Objetivo: Este estudo irá explorar a influência dos exercícios regulares de dança física na forma, função e qualidade do corpo de adultos mais velhos e de meia-idade, e fornecerá uma base científica para o papel da dança física no fitness nacional. Métodos: Este estudo recrutou 20 pessoas saudáveis, de meia-idade e idosos de um clube esportivo sem experiência profissional em dança durante três meses de treinamento. As primeiras duas semanas foram pré-experimentos cinco vezes por semana. Cada tempo de exercício foi de 60 minutos. As últimas dez semanas foram experimentos formais, duas vezes por semana, 90 minutos cada vez, sem nenhum outro exercício físico na vida cotidiana. Ao comparar a forma corporal, a função física e o índice de aptidão física antes e depois do experimento, o impacto da dança esportiva na aptidão física saudável de adultos mais velhos e de meia-idade é avaliado. Resultados: Após três meses de exercício físico de dança com diferentes estilos de dança, nos homens, o índice de IMC, o percentual de gordura corporal, a circunferência da cintura, a circunferência do quadril e a circunferência da coxa diminuíram, mas não houve diferença significativa. Nas mulheres, o índice de IMC, o percentual de gordura corporal $(P<0,01)$, a circunferência da cintura $(P<0,05)$, a pressão arterial diastólica $(P<0,01)$, o corpo sentado inclinado para frente $(P<0,05)$ e com um pés e olhos fechados aumentaram. Nas mulheres, os índices de força de preensão $(P<0,01)$, de inclinação para a frente na posição sentada $(P<0,055)$ e com um pé com os olhos fechados aumentaram. Conclusões: Sugere-se que o exercício de dança esportiva aeróbica de intensidade moderada de longa duração pode melhorar a forma corporal de adultos mais velhos e de meia idade e ajudar a aumentar a aptidão física; enquanto isso, a dança esportiva pode efetivamente melhorar a função cardiovascular de indivíduos de meia-idade e idosos. Nível de evidência Il; Estudos terapêuticos: investigação dos resultados do tratamento.

Descritores: Dança; Adultos de meia-idade e idosos; Atividades de lazer; Exercício físico. 


\section{RESUMEN}

Introducción: La danza deportiva es ampliamente conocida como un juego competitivo, pero como actividad de ocio hay poca investigación sobre la eficacia en la salud y el estado físico humanos. La danza deportiva, como ejercicio fisico popular a nivel nacional, tiene importantes efectos en la promoción de la salud. En la actualidad, las investigaciones nacionales y extranjeras se centran principalmente en el impacto de la danza deportiva en hombres y mujeres jóvenes. Objetivo: Este estudio explorará la influencia de los ejercicios regulares de danza física en la forma, función y calidad del cuerpo de los adultos mayores y de mediana edad, y proporcionará una base científica para el papel de la danza física en la aptitud nacional. Métodos: Este estudio reclutó a 20 miembros sanos de mediana edad y ancianos de un club deportivo sin experiencia profesional en danza durante tres meses de entrenamiento. Las dos primeras semanas eran experimentos previos cinco veces por semana. Cada tiempo de ejercicio fue de 60 minutos. Las últimas diez semanas eran experimentos formales, dos veces por semana, 90 minutos cada vez, sin otros ejercicios físicos en la vida cotidiana. Al comparar la forma del cuerpo, la función física y el índice de aptitud fisica antes y después del experimento, se evalúa el impacto de la danza deportiva en la aptitud física saludable de los adultos mayores y de mediana edad. Resultados: Después de tres meses de ejercicio físico de baile con diferentes estilos de baile, en los hombres, el índice de IMC, el porcentaje de grasa corporal, la circunferencia de la cintura, la circunferencia de la cadera y la circunferencia del muslo disminuyeron, pero no hubo diferencia significativa. En las mujeres, el índice de IMC, el porcentaje de grasa corporal ( $P<0.01)$, la circunferencia de la cintura $(P<0.05)$, la presión arterial diastólica $(P<0.01)$, el cuerpo sentado inclinado hacia adelante $(P<0.05)$ y con un pie y ojos cerrados aumentaron. En las mujeres, aumentaron los índices de fuerza de agarre $(P<0.01)$, de inclinación hacia adelante en posición sentada $(P<0.055)$ y con un pie con los ojos cerrados. Conclusiones: Se sugiere que el ejercicio de danza deportiva aeróbica de intensidad moderada a largo plazo puede mejorar la forma del cuerpo de los adultos mayores y de mediana edad y ayudar a aumentar la aptitud física; mientras tanto, la danza deportiva puede mejorar eficazmente la función cardiovascular de sujetos de mediana edad y ancianos. Nivel de evidencia Il; Estudios terapéuticos: investigación de los resultados del tratamiento.

Descriptores: Baile; Adultos de mediana edad y mayores; Actividades recreativas; Ejercicio físico.

\section{INTRODUCTION}

At present, as a nationwide fitness program that emerging people are willing to participate in, sports dance is one of the most popular sports fitness activities for middle-aged and older adults. At present, the research progress of sports dance on improving human body fitness's effectiveness mostly focuses on young people and college students, and there are few research pieces on middle-aged and older adults. Reports on middle-aged and older people's fitness effects through sports dance are also relatively rare. ${ }^{1}$ This article launches research on the effect of middle-aged and older people using sports dance for fitness. It explores the effect of regular sports dance exercise on body shape. The influence of function and quality provides a scientific basis for sports dance in national fitness.

\section{METHOD}

\section{Research objects}

This study recruited 20 healthy middle-aged and elderly members of a leisure sports dance club without professional dance experience as subjects, including eight men and 12 women. The subjects were all 40-65 years old; the average age of men was $58.13 \pm 4.67$ years, and the average age of women was $52.67 \pm 6.56$ years. Due to participants' screening conditions, the number of male participants is short of 2 , and the number of female participants is two more. ${ }^{2}$ The subjects live in the community near the club, which is easy to manage.

\section{EXPERIMENTAL STEPS}

\section{Preparation before exercise intervention}

We used questionnaires to understand the subjects' physical condition, life, diet, exercise habits, disease history, exercise contraindications, and other factors that impact the experimental results, inform the research content subjects, and sign the informed consent.

\section{Test index}

Body shape: height, weight, BMl index, body fat rate, waist circumference, hip circumference, thigh circumference; physical functions: systolic blood pressure, diastolic blood pressure, resting heart rate, 20-meter round trip (maximum oxygen uptake); physical fitness: grip, stand on one foot with eyes closed and bend forward while sitting.

\section{Experimental process:}

1. Carry out preliminary measurements of body shape, function, and fitness indicators for all subjects. Body shape indicators include height, weight, BMI index, waist circumference, hip circumference, thigh circumference, body fat percentage; body function indicators include systolic blood pressure, Diastolic blood pressure, resting heart rate, maximum oxygen uptake; physical fitness indicators include grip strength, standing with one foot closed, and sitting forward bending.

2. Three-month sports dance intervention was performed on the subjects. Retired professional sports dance athletes will teach middle-aged and elderly subjects. The first two weeks are pre-experiments, five times a week, each exercise time is 60 minutes, and the next ten weeks are formal experiments, with two exercises per week. ${ }^{3}$ Do not participate in any other physical exercises during daily life for 90 minutes. The subject wears a heart rate monitor to monitor the exercise heart rate in real-time during the exercise, and it is controlled at 60\%-70\% of the maximum heart rate. The researcher records the subject's exercise intensity to ensure the effectiveness of the subject's exercise effect. Table 1 shows the subjects' exercise heart rate records at different time points during the first five training sessions of the pre-experiment to control their heart rate ranges for the entire class according to the training session in the future. 3. In the first two weeks, the subjects will practice five different sports dances: rumba, chacha, bullfighting, samba, and cowboy five times a week, each for 60 minutes; starting from the 3rd week, every two weeks, Perform one dance practice, two times a week, 90 minutes each time. 
Table 1. Exercise heart rate monitoring.

\begin{tabular}{c|c|c|c|c}
\hline \multirow{2}{*}{ Date } & Gender & $\begin{array}{c}\text { Heart rate at 20 } \\
\text { minutes (BMP) }\end{array}$ & $\begin{array}{c}\text { Heart rate at 40 } \\
\text { minutes (BMP) }\end{array}$ & $\begin{array}{c}\text { Heart rate at 60 } \\
\text { minutes (BMP) }\end{array}$ \\
\hline \multirow{2}{*}{ Monday } & male & $123.25 \pm 13.85$ & $119.88 \pm 7.75$ & $114.50 \pm 3.51$ \\
\cline { 2 - 5 } & Female & $124.33 \pm 18.02$ & $118.75 \pm 6.30$ & $116.75 \pm 6.28$ \\
\hline \multirow{2}{*}{ Tuesday } & male & $114.75 \pm 3.50$ & $113.63 \pm 4.27$ & $112.88 \pm 3.72$ \\
\cline { 2 - 5 } & Female & $115.75 \pm 5.17$ & $114.33 \pm 5.66$ & $113.33 \pm 5.00$ \\
\hline \multirow{2}{*}{ Wednesday } & male & $112.75 \pm 3.24$ & $112.00 \pm 5.01$ & $111.88 \pm 4.26$ \\
\cline { 2 - 5 } & Female & $113.83 \pm 5.69$ & $113.83 \pm 3.51$ & $113.83 \pm 2.41$ \\
\hline \multirow{2}{*}{ Thursday } & male & $110.88 \pm 4.26$ & $112.38 \pm 3.85$ & $113.00 \pm 2.45$ \\
\cline { 2 - 5 } & Female & $113.00 \pm 2.37$ & $112.83 \pm 3.88$ & $112.17 \pm 4.24$ \\
\hline
\end{tabular}

During the experiment period of 10 weeks, the five dance types practiced for two weeks. After the end of the 12-week intervention, the subjects were subjected to post-tests of various physical indicators.

\section{Statistics}

The experimental data of this study used the SPSS13.0 software package for statistical analysis. A paired-sample t-test was performed on the body shape, physical function, and physical fitness indicators before and after the intervention. $P<0.01$ represents a statistically significant difference. ${ }^{4-5}$

\section{RESULTS}

\section{Comparison of body shape changes before and after sports dance intervention}

Table 2 shows that after three months of physical dance exercise, male subjects' BMI, body fat percentage, waist circumference, hip circumference, and thigh circumference index decreased. The BMI index decreased from $22.70 \mathrm{~kg} / \mathrm{m}^{2}$ to $22.59 \mathrm{~kg} / \mathrm{m}^{2}$. The body fat percentage decreased by $0.14 \%$ from $21.20 \%$ to $21.06 \%$; the waist circumference decreased by $0.68 \mathrm{~cm}$ from $80.06 \mathrm{~cm}$ to $79.38 \mathrm{~cm}$; the hip circumference decreased by $0.19 \mathrm{~cm}$ from $91.13 \mathrm{~cm}$ to $90.94 \mathrm{~cm}$; the thigh circumference decreased from $53.38 \mathrm{~cm}$ It dropped by $1.25 \mathrm{~cm}$ to $52.13 \mathrm{~cm}$; however, there was no significant difference in each index. On the whole, it shows that sports dance has a certain effect on improving the body shape of middle-aged and older people to a certain extent.

Table 3 shows that the BMI index, body fat rate, waist circumference, hip circumference, and thigh circumference indexes of female subjects all decreased, and the BMI index decreased from $22.0 \mathrm{~kg} / \mathrm{m}^{2}$ to $21.83 \mathrm{~kg} /$ $\mathrm{m}^{2}$ by $0.17 \mathrm{~kg} / \mathrm{m}^{2}$; body fat rate decreased from 28.52 to $28.19 \%$ decreased by $0.33 \%(P<0.01)$; waist circumference decreased by $0.63 \mathrm{~cm}$ from $73.21 \mathrm{~m}$ to $72.58 \mathrm{~cm}(\mathrm{P}<0.05)$ hip circumference decreased by $0.13 \mathrm{~cm}$ from $90.67 \mathrm{~cm}$ to $90.54 \mathrm{~cm}$; thigh circumference decreased from $51.63 \mathrm{~cm}$ to $51.29 \mathrm{~cm}$ decreased by $0.34 \mathrm{~cm}$ : the body fat percentage index has a highly significant difference $(P<0.01)$, and the waist circumference index has a significant difference $(P<0.05)$. (Table 3 )

\section{Comparison of physical function changes before and after sports dance intervention}

Table 4 shows that after three months of physical dance exercise, the male subjects' systolic blood pressure, diastolic blood pressure, and resting heart rate indicators all decreased, and the systolic blood pressure decreased from $148.75 \mathrm{mmHg}$ to $142.63 \mathrm{mmHg}$ by $6.12 \mathrm{mmHg}(P<0.05)$; Diastolic blood pressure decreased from $92.88 \mathrm{mmHg}$ to $86.50 \mathrm{mmHg}$ by $6.38 \mathrm{mmHg}(P<0.01)$; resting heart rate decreased from 78.00 beats/ minute to 76.13 beats/minute by 1.87 beats/minute; systolic blood pressure indicators had significant differences, and diastolic blood pressure indicators had Significant high difference; at the same time the maximum oxygen uptake index has been improved, the maximum oxygen uptake increased from $30.49 \mathrm{~mL} / \mathrm{kg} \cdot \mathrm{m}$ to $30.58 \mathrm{~mL} / \mathrm{kg} \cdot \mathrm{m}$ by $0.09 \mathrm{~mL} / \mathrm{kg} \cdot \mathrm{m}$; but there was no significant difference.
Table 2. Changes of male body shape indexes before and after the intervention of sports dance.

\begin{tabular}{c|c|c|c|c|c}
\hline Index & $\begin{array}{c}\text { Number of } \\
\text { people }(\mathbf{n})\end{array}$ & $\begin{array}{c}\text { Before } \\
\text { intervention }\end{array}$ & $\begin{array}{c}\text { After the } \\
\text { intervention }\end{array}$ & $\mathbf{t}$ & $\mathbf{P}$ \\
\hline BMI $\left(\mathrm{kg} / \mathrm{m}^{2}\right)$ & 8 & $22.70 \pm 2.47$ & $22.59 \pm 2.38$ & 1.317 & 0.229 \\
\hline Body fat rate $(\%)$ & 8 & $21.20 \pm 4.54$ & $21.06 \pm 4.43$ & 1.629 & 0.147 \\
\hline Waist circumference $(\mathrm{cm})$ & 8 & $80.06 \pm 9.41$ & $79.38 \pm 8.60$ & 1.429 & 0.196 \\
\hline Hip circumference $(\mathrm{cm})$ & 8 & $91.13 \pm 4.85$ & $90.94 \pm 4.31$ & 0.397 & 0.703 \\
\hline Thigh circumference $(\mathrm{cm})$ & 8 & $53.38 \pm 2.00$ & $52.13 \pm 1.96$ & 1.402 & 0.204 \\
\hline
\end{tabular}

Table 3. Changes of female body shape indexes before and after the intervention of sports dance.

\begin{tabular}{c|c|c|c|c|c}
\hline Index & $\begin{array}{c}\text { Number of } \\
\text { people }(\mathbf{n})\end{array}$ & $\begin{array}{c}\text { Before } \\
\text { intervention }\end{array}$ & $\begin{array}{c}\text { After the } \\
\text { intervention }\end{array}$ & $\mathbf{t}$ & $\mathbf{P}$ \\
\hline BMl $(\mathrm{kg} / \mathrm{m})$ & 12 & $22.00 \pm 1.74$ & $21.83 \pm 1.81$ & 0.902 & 0.386 \\
\hline Body fat rate $(\%)$ & 12 & $28.52 \pm 2.96$ & $28.19 \pm 2.79$ & 3.377 & 0.006 \\
\hline Waist circumference $(\mathrm{cm})$ & 12 & $73.21 \pm 6.45$ & $72.58 \pm 6.06$ & 3.045 & 0.011 \\
\hline Hip circumference $(\mathrm{cm})$ & 12 & $90.67 \pm 4.26$ & $90.54 \pm 4.75$ & 0.405 & 0.693 \\
\hline Thigh circumference $(\mathrm{cm})$ & 12 & $51.63 \pm 2.81$ & $51.29 \pm 3.67$ & 0.697 & 0.5 \\
\hline
\end{tabular}

Table 4. Changes of physical fitness indicators before and after the intervention of male sports dance.

\begin{tabular}{c|c|c|c|c|c}
\hline Index & $\begin{array}{c}\text { Number of } \\
\text { people }(\mathbf{n})\end{array}$ & $\begin{array}{c}\text { Before } \\
\text { intervention }\end{array}$ & $\begin{array}{c}\text { After the } \\
\text { intervention }\end{array}$ & $\mathbf{t}$ & $\mathbf{P}$ \\
\hline Grip strength $(\mathrm{kg})$ & 8 & $37.38 \pm 7.06$ & $37.61 \pm 6.54$ & -0.692 & 0.511 \\
\hline $\begin{array}{c}\text { Sitting forward } \\
\text { bending (cm) }\end{array}$ & 8 & $7.06 \pm 3.73$ & $7.66 \pm 3.33$ & -2.592 & 0.036 \\
\hline $\begin{array}{c}\text { Standing on one foot } \\
\text { with eyes closed(s) }\end{array}$ & 8 & $13.92 \pm 9.17$ & $16.53 \pm 7.94$ & -1.81 & 0.113 \\
\hline
\end{tabular}

\section{Comparison of physical fitness changes before and after sports dance intervention}

Table 6 shows that after three months of physical dance exercise, male subjects' grip strength increased from $37.38 \mathrm{~kg}$ to $37.61 \mathrm{~kg}$ by $0.23 \mathrm{~kg}$; the sitting position increased by $0.6 \mathrm{~cm}$ from $7.06 \mathrm{~cm}$ to $7.66 \mathrm{~cm}(P<0.05)$. Standing with feet closed and eyes increased from $13.92 \mathrm{~s}$ to $16.53 \mathrm{~s}$ by $2.61 \mathrm{~s}$; there was a significant difference in flexion index in the sitting position $(P<0.05)$.

Table 7 shows that after three months of physical dance exercise, female subjects' grip strength increased from $23.16 \mathrm{~kg}$ to $23.77 \mathrm{~kg}$ by $0.61 \mathrm{~kg}(\mathrm{P}<0.01)$; sitting body forward bending increased by $11.28 \mathrm{~cm}$ to $12.08 \mathrm{~cm}$. A significant difference $(P<0.05)$, standing on one foot with eyes closed increased by $1.42 \mathrm{~s}$ from $20.89 \mathrm{~s}$ to $22.31 \mathrm{~s}$ : on the whole, it shows that to a certain extent, sports dance has a particular effect on the physical fitness of middle-aged and older adults.

\section{DISCUSSION}

The data of the middle-aged and older people in this experiment after three months of physical dance exercise showed that the resting heart rate of male subjects decreased by 1.87 beats per minute; the systolic blood pressure at rest decreased by $6.12 \mathrm{mmHg}(\mathrm{P}<0.5)$, and the diastolic blood pressure decreased by 6.38 The $\mathrm{mmHg}(\mathrm{P}<0.01)$ systolic blood pressure index has a significant difference.

It needs to quickly transport oxygen and nutrients to the skeletal muscles and muscles [6]. On the other hand, other organs need to excrete metabolites from the body as soon as possible. Sports dance does not continuously stimulate the body like running and other aerobic exercises, so the maximum oxygen uptake index's improvement is relatively insignificant, but it has improved. It reflects the long-term regularity of aerobic sports dance exercises that can improve middle-aged and older people's aerobic capacity and promote cardiopulmonary function improvement. Sports dance is a fitness project that the public loves and can develop middle-aged and older people's aerobic endurance. 


\section{CONCLUSION}

During the three-month regular physical dance exercise intervention, the BMl index, body fat percentage, waist circumference, hip circumference, and thigh circumference of male and female middle-aged and elderly subjects decreased. In particular, women's body fat rates have changed significantly, suggesting that long-term moderate-intensity, long-term aerobic sports, and dance exercise can better improve middle-aged and older people's body shape. The systolic blood pressure and diastolic blood pressure of male and female middle-aged and elderly subjects decreased, and the maximum oxygen uptake increased. Although the systolic blood pressure of men was still higher than the normal range after exercise, the long-term adherence to the reduction effect would be more significant; overall, in other words, it reflects that dancing sports can effectively improve the cardiovascular function of middle-aged and elderly subjects. Male and female middle-aged and elderly subjects improved significantly in sitting forward flexion. Female grip strength changed significantly, and arm muscle strength increased, suggesting that middle-aged and older people participating in sports dance can increase physical fitness.

All authors declare no potential conflict of interest related to this article

AUTHORS' CONTRIBUTIONS: Each author has made significant personal contributions to the manuscript. Caixia Wang analyzed and explained the relevant data and played a leading role in writing the full text. Aibo Wang made major contributions to the research background and the collection of research literature and was the main contributor to the manuscript writing. Lei Li made a great contribution to the questionnaire survey. All authors read and approved the final manuscript.

\section{REFERENCES}

1. Predovan D, Julien A, Esmail A, Bherer L. Effects of dancing on cognition in healthy older adults: a systematic review. J Cogn Enhanc. 2019;3(2):161-7.

2. Thieser S, Dörfler J, Rudolph I, Wozniak T, Schmidt T, Hübner J. Influence of ballroom dancing on fatigue, body image, self-efficacy, and endurance of cancer patients and their partners. Med Oncol. 2021;38(2):15.

3. Castan-Vicente F, Bohuon A. Emancipation through sport? Feminism and medical control of the body in interwar France. Sport in History. 2020[cited 202121 Jun];40(2):235-56. Available from: https://www.tandfonline.com/doi/abs/10.1080/17460263.2019.1652845

4. Chen W, Hammond-Bennett A, Hypnar A, Mason S. Health-related physical fitness and physical activity in elementary school students. BMC Public Health. 2018;18(1):195.

5. Vertinsky $P$. This dancing business is more hazardous than any "He-Man'sport": Ted Shawn and His Men Dancers. Sociology of Sport Journal. 2018;35(2):168-77.

6. Kaźmierczak A. Physical education and sport in pedagogical concepts-historical context. J Educ Health Sport. 2018;8(8):281-92 